\title{
Efficient Solid Waste Management in Prai Industrial Area through GIS using Dijkstra and Travelling Salesman Problem Algorithms
}

\author{
Gaeithry Manoharam¹, Mohd. Tahir Ismail', Ismail Ahmad Abir ${ }^{2}$ and \\ Majid Khan Majahar Ali ${ }^{1 *}$ \\ ${ }^{1}$ School of Mathematical Sciences, Universiti Sains Malaysia, 11800 USM, Penang, Malaysia \\ ${ }^{2}$ School of Physics, Universiti Sains Malaysia, 11800 USM, Penang, Malaysia
}

\begin{abstract}
The fourth industrial revolution (IR 4.0) supports new solid waste management and effective routing system for collection and transport of solid wastes, especially in achieving Penang 2030 vision to become a pollution free smart city. This study will enhance Seberang Perai Municipal Council (MBSP) solid waste routing system in Prai industrial area by implementing Dijkstra and Travelling Salesman Problem (TSP) algorithms using Geographic Information System version 10.1. The route optimization study involved 24 companies in Phase I, Phase II, and Phase IV of Prai industrial area. The authority is currently using only one route to transfer the waste-to-waste transfer station. The Dijkstra algorithm can optimize alternative route 1 distance by $19.74 \%$ whereby alternative route 2 ended up with extra distance by $3.73 \%$ compared to existing single route used by MBSP. The forward Dijkstra algorithm involves single direction route with cleaning depot (source) as starting point and waste transfer station (destination) as ending point. TSP algorithm is having advantage with return direction route. The alternative route 1 evaluated through TSP algorithm gave shorter distance by $6.61 \%$ compared to existing route. Alternative route 1 evaluated through Dijkstra algorithm is potential to save fuel cost by $19.75 \%$. Existing route carries $9.2 \%$ per year of transportation carbon emission level. The alternative route 1 assessed through Dijkstra and TSP

ARTICLE INFO

Article history:

Received: 08 September 2020

Accepted: 07 December 2020

Published: 31 July 2021

DOI: https://doi.org/10.47836/pjst.29.3.02

E-mail addresses:

gaeithry@gmail.com (Gaeithry Manoharam)

m.tahir@usm.my (Mohd. Tahir Ismail)

iahmadabir@usm.my (Ismail Ahmad Abir)

majidkhanmajaharali@usm.my (Majid Khan Majahar Ali)

* Corresponding author algorithms reported lower carbon emission level at $7.4 \%$ per year and $8.6 \%$ per year, respectively. Findings of this study can help in improving MBSP's routing system and realize Penang 2030 vision.

Keywords: Carbon emission, Dijkstra's algorithm, geographic information system, solid waste management, transportation
\end{abstract}




\section{INTRODUCTION}

Modernization and industrialization keep increase managing cost of municipal facilities with waste management operating cost at the top (Omran et al., 2009). Malaysia, a fastgrowing country in Asia with no exception to the dilemma of increase in waste generation (Williams, 2012) due to the rapid development and industrialization. In most municipalities in Malaysia, the local government is the one supervising solid waste collection (Penang State Government, 2016). In year 2014, Malaysia spent RM 3.018 billion to cover for the operating expenses of waste management in the country (National Solid Waste Management Department, 2013). Seberang Perai Municipal Council(MBSP) allocated RM 1.241 billion between 2006 and 2010 to cover the cost of solid waste management (SWM). The state and local governments are still responsible for the operating cost on top of financial support by Federal Government for the fundamental expenses. Rise in fuel cost is indirectly impacting operational costs further (Penang State Government, 2016). Increase in industrial zones and living estates, surging waste generation hence becoming a crucial issue all over the world in SWM including Penang, Malaysia (Kumpulan Utusan, 2017).

Transportation is a primary component of any SWM system. It is important in transferring waste from the point of generation to the transfer station or final landfill site (Zam et al., 2007). MBSP faced challenges to identify distance between waste collection points especially in Prai industrial area. It is important to optimize the travelling distance from one waste collection point to another. This study was initiated to identify an optimal route for waste collections and transportation using Geographic Information System (GIS) to optimize the travelling distance, time, and fuel consumption.

The application of Geographic Information System (GIS) in SWM by different countries shown in Table 1. Table 1 is also revealing limited studies done in Malaysia covering the scope of SWM at industrial areas. Additionally, there is no evidence on any study conducted at Prai industrial area using Dijkstra and Traveling Salesman Problem (TSP) algorithms.

This research focused on route optimization of SWM by MBSP at Prai industrial area. The intention of this study is to discover alternative route using GIS Software, compare the route established by MBSP and assess shortest route identified by GIS. Both Dijkstra and TSP algorithms used to identify the minimum distance path. This leads to possible savings in operating cost and waste transferring time. The comparison summary of fuel cost and carbon emissions is a useful input for management of MBSP to march towards green city by 2030 .

Following aspects taken into consideration for this research:

1. Transportation of municipal waste generated in Prai industrial area to Ampang Jajar Waste Transfer Station.

2. Directed graph mechanism used for Dijkstra algorithm and Hamilton cycle mechanism used for TSP algorithm. 
Table 1

The practice of solid waste management in different countries

\begin{tabular}{|c|c|c|c|c|}
\hline No & Author & Location & Method & Criteria \\
\hline 1 & $\begin{array}{l}\text { (Anghinolfi et al., } \\
\text { 2013) }\end{array}$ & Italy & GIS \& MILP Model & $\begin{array}{l}\text { Minimize collection and } \\
\text { transportation costs. }\end{array}$ \\
\hline 2 & $\begin{array}{l}\text { (Chipumuro et al., } \\
\text { 2014) }\end{array}$ & Zimbabwe & Dijkstra Algorithm & $\begin{array}{l}\text { Reduction of } 10.45 \% \text { in the total } \\
\text { distance travelled. }\end{array}$ \\
\hline 3 & (Bovwe, et al., 2016) & Nigeria & GIS\& Ant Colony & \\
\hline 4 & (Bhambulkar, 2011) & India & $\begin{array}{l}\text { ArcGIS Network } \\
\text { Analyst }\end{array}$ & Route length \\
\hline 5 & (Ahmad, 2016) & Qatar & GIS & Time duration \\
\hline 6 & (Ghose et al., 2006) & India & GIS & Route Optimization \\
\hline 7 & (Patel et al., 2016) & India & Network Analyst & \\
\hline 8 & (Beijoco et al., 2011) & Portugal & GIS & \\
\hline 9 & (Zam et al., 2007) & Phuentsholing & GIS & \\
\hline 10 & $\begin{array}{l}\text { (Shamshiry et al., } \\
\text { 2011) }\end{array}$ & Malaysia & $\begin{array}{l}\text { Response surface } \\
\text { methods (RSM) }\end{array}$ & $\begin{array}{l}\text { Less operation cost and fuel } \\
\text { consumption. }\end{array}$ \\
\hline 11 & (Singh et al., 2014) & Kanpur & Dijkstra Algorithm & $\begin{array}{l}\text { Get the shortest path and shortest } \\
\text { route for one- way, two-way }\end{array}$ \\
\hline 12 & (Kinobe et al., 2015) & Kampal & GIS & $\begin{array}{l}\text { Diminish the costs of managing } \\
\text { wastes and environmental. }\end{array}$ \\
\hline 13 & $\begin{array}{l}\text { (Nguyen-Trong et al., } \\
\text { 2017) }\end{array}$ & Vietnam & GIS & Reduce operation cost of SWM \\
\hline 14 & (Tavares et al., 2008) & Portugal & $3 \mathrm{D}$ route modelling & $\begin{array}{l}\text { Savings in fuel \& shortest } \\
\text { distance }\end{array}$ \\
\hline
\end{tabular}

3. Carbon emission rate calculated based on weight $(\mathrm{kg})$ of collected waste and diesel used by trucks in a month to travel between Prai industrial area and Ampang Jajar Waste Transfer Station.

4. Only solid waste consist leftover food, plastic and paper is considered as waste for the purpose of this study. Chemical, metal, and landscaping waste are excluded from this study.

5. The waste collection schedule limited to period between 8 am and $4 \mathrm{pm}$. The travelling time between points is also excluded in this study.

Network analysis finds the most effective path to solve a network problem by calculating the shortest route with lowest cost on the network from one stop to another or from one stop to several stops (Stewart, 2005). The layout of the waste collection route needs to be well-planned, and the collection should adhere to the planned schedule, as it will help to reduce the unnecessary amount in the budget. Penang control their SWM autonomously. City Council of Penang Island (MBPP) is the administrative body for the island while Municipal Council of Seberang Perai (MBSP) manages the mainland area (Omran et al., 2009). Penang Island is divided into eight zones, consist of Tanjung Tokong, 
Batu Maung, Gelugor, Air Itam, Pulau Tikus, Jelutong, Padang Kota Lama, and Balik Pulau. On the other hand, Seberang Perai divided into northern, central, and southern zones which governed by MBSP.

Malaysia's industrial areas are expanding annually. Free industrial zones located in Seberang Perai are second largest industrial area for the State of Penang. The Prai industrial area is divided into four phases, i.e., Prai Industrial Zone Phase I, II, III, and IV, and about 440 industries are operating in these industrial zones (Penang State Government, 2016). According to a MBSP Operation Manager, even though there are 440 companies in Prai Industrial Zone, MBSP only collects solid wastes from 24 companies who pay fees for garbage collection. MBSP collects about $710 \mathrm{~kg}$ of wastes in a day, and these companies produce about 252.72 tonnes of waste in a year.

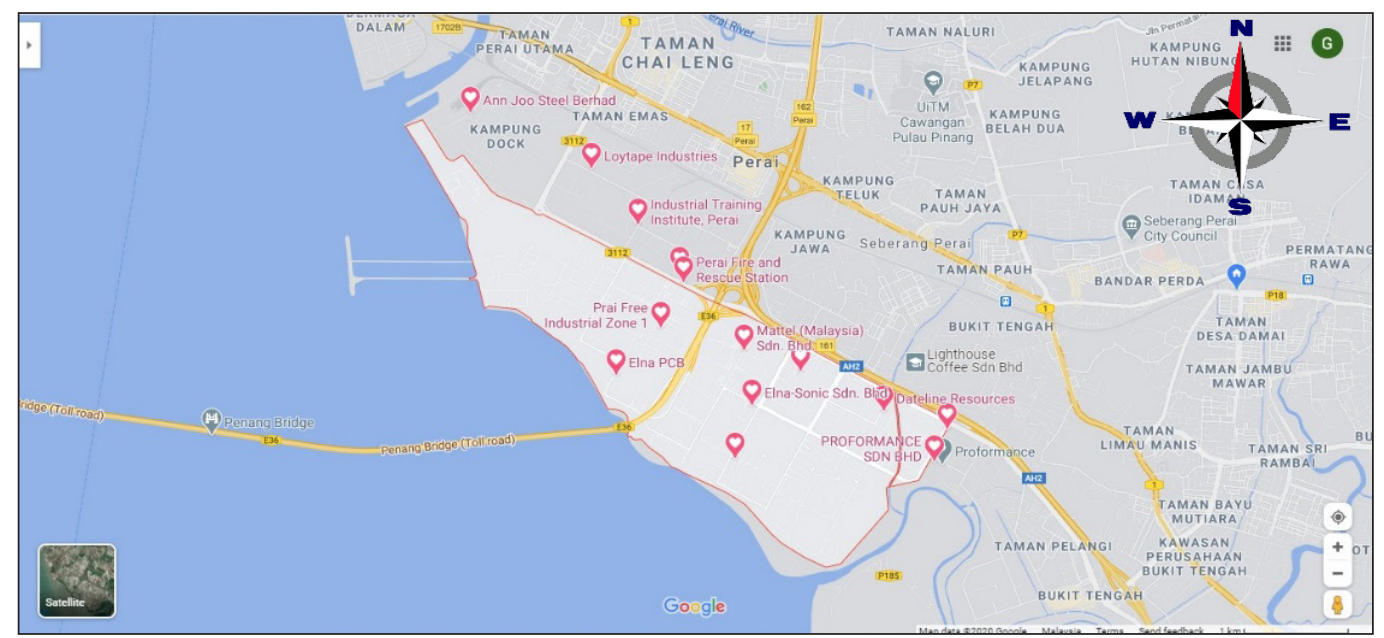

Figure 1. The map of Prai Industrial Zone Phase I research area

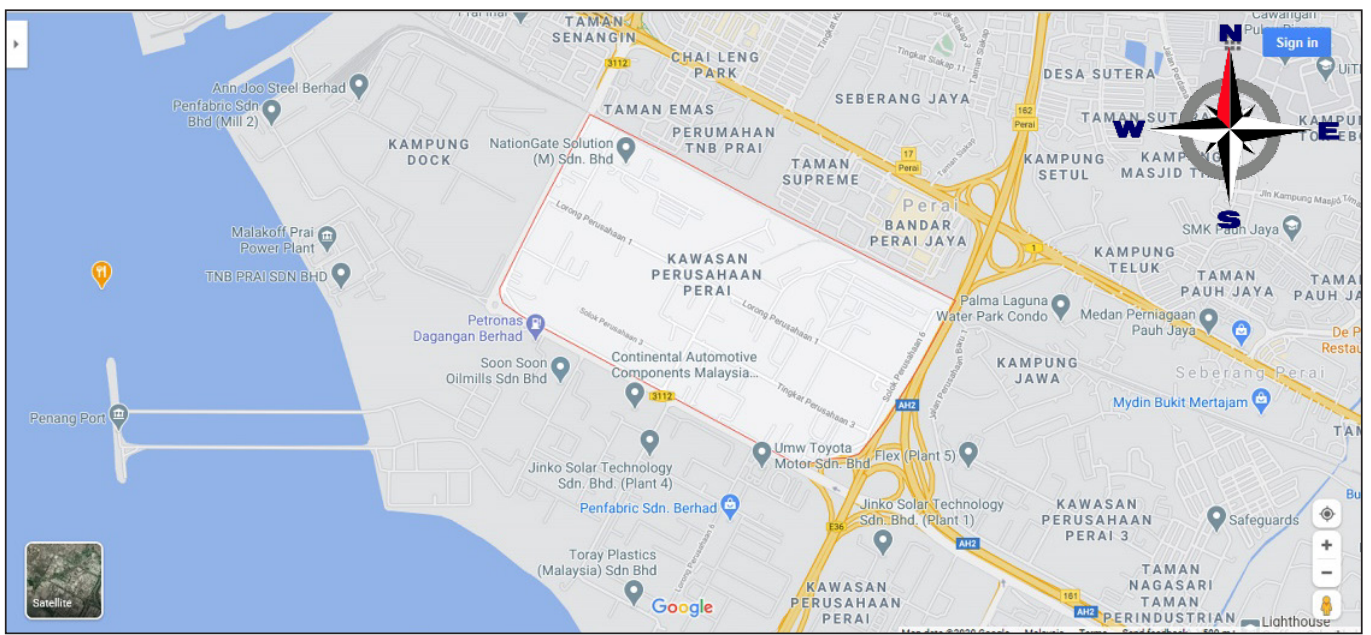

Figure 2. The map of Prai Industrial Zone Phase II research area 


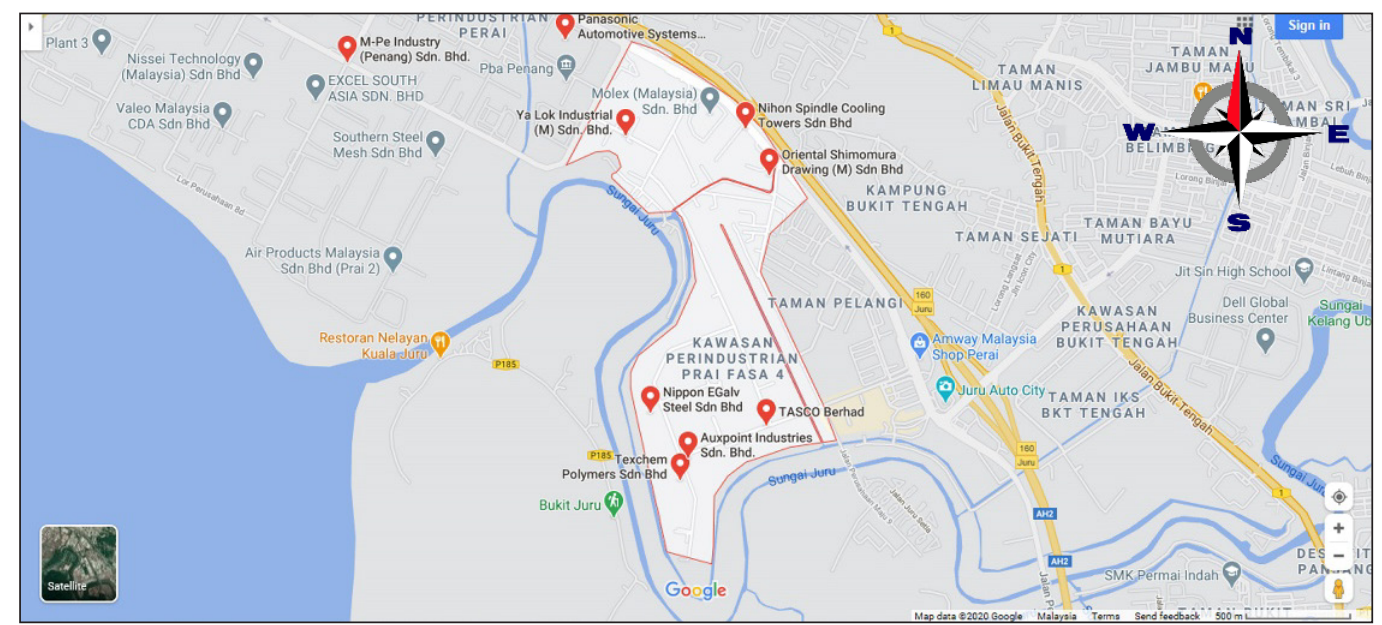

Figure 3. The map of Prai Industrial Zone Phase IV research area

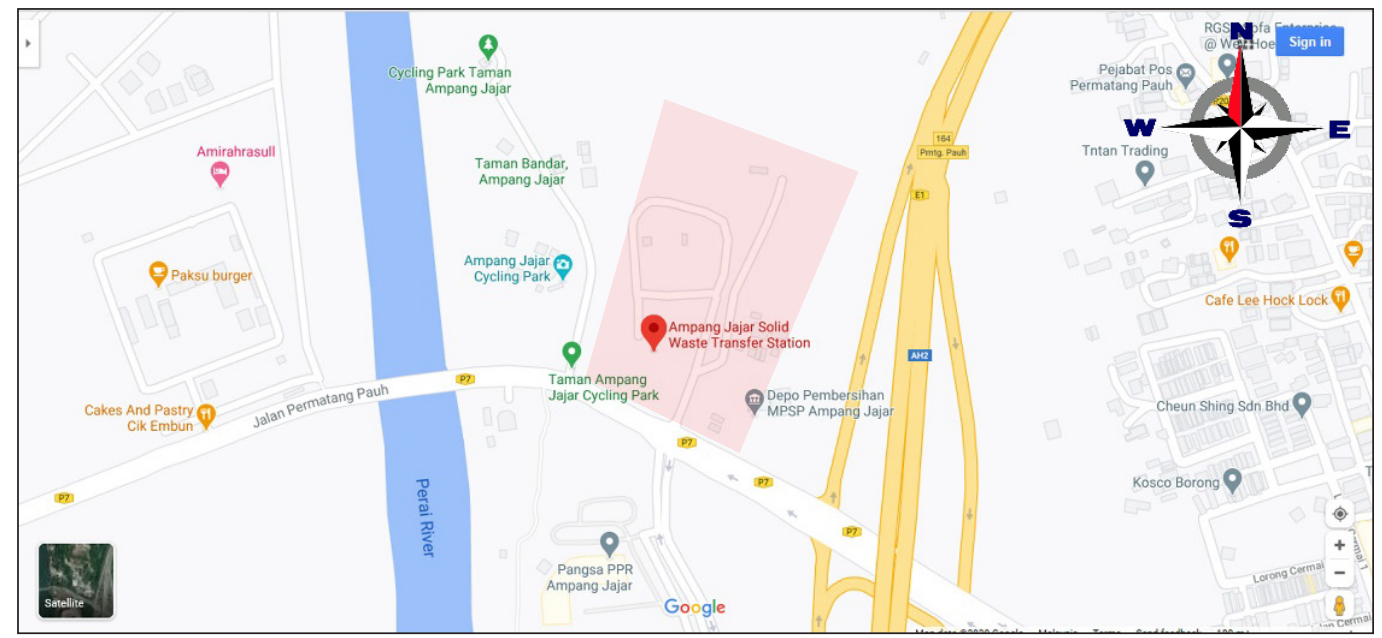

Figure 4. The map of Ampang Jajar waste transfer station research area

In this study paper, firstly the existing route used by MBSP and alternative routes for Prai Industrial Zone Phase I, II and IV were assessed using GIS. Secondly, the shortest path was determined using Dijkstra and TSP algorithms. Fuel cost and carbon emissions rate were determined for existing and alternative routes as a final part of this study. The same method has been used in Vietnam, to reduce the operation cost of SWM (NguyenTrong et al., 2017).

Figures 1-3 illustrate the map of Prai Industrial Zones of Penang mainland. The location indicated in Figure 4 represent the Ampang Jajar waste transfer station. MBSP collects and segregates all industrial waste from selected factories at the waste transfer station (Google Map view). 


\section{MATERIALS AND METHODS}

\section{Data}

Data collection is done after reviewing previous studies. This study used both quantitative and qualitative methods. Quantitative data from MBSP was obtained including collection point, collection time, distance travelled, and quantity of labour involved. Meanwhile, a qualitative survey was conducted in Prai Industrial Zone using Global Positioning System (GPS) coordinate for the 24 companies located in Phase I, II and IV.

After data collection, the Dijkstra and TSP algorithms were used in ArcGIS version 10.1 to construct the shortest route. Then the shortest route will be compared with the existing and other alternative routes. The classic Dijkstra algorithm clarifies the single-source, shortest-path problem of the weighted graph in the ArcGIS. The route solver has the option to generate the optimal strings of visited stop locations while TSP is a combination problem solver, meaning there is no straightforward way to find the best sequence. Metaheuristics method used by TSP is also handles time windows during collection stops. It finds the optimal stops to visit and produce shortest distance and time. Figure 5 shows the process flow chart followed during the research.

Data collection was done through interviewing Operation Manager, Industrial Zone from MBSP. It was revealed during the interview session that single garbage truck is being occupied to collect industrial waste from Prai Industrial Zones. Solid waste is collected daily from those 24 paying companies between 7

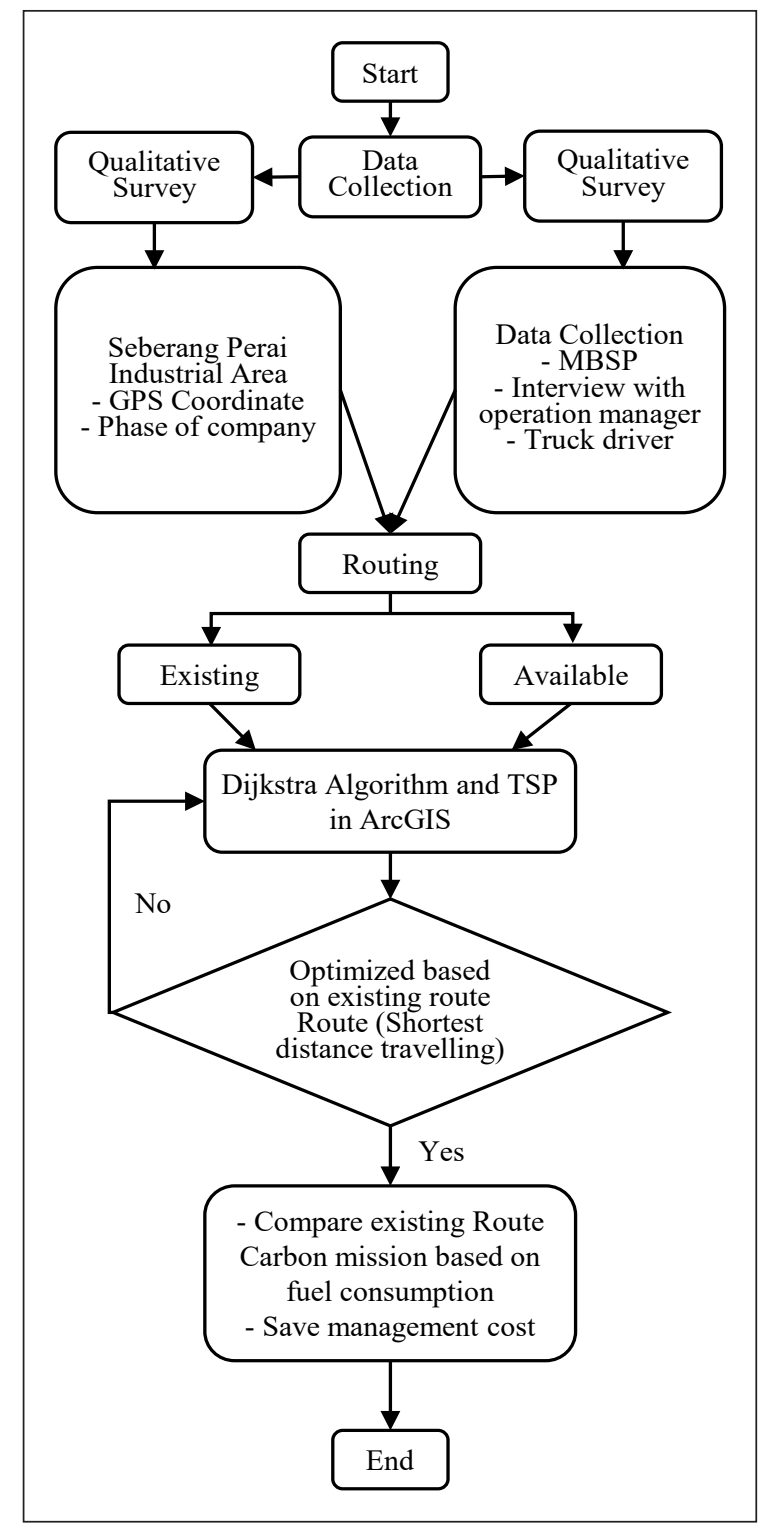

Figure 5. Research process flow chart (Self-design) 
a.m. and 7 p.m. Waste collection fees to follow the contract transpired between industries management and MBSP. The number of companies which are paying collection fees to MBSP are listed in Table 2 according to phases of Prai Industrial Zone.

Table 2

Number of industries that paying collection fees in the Prai Industrial Zones

\begin{tabular}{ccc}
\hline Prai Industrial Zone & Total Factories & Fee Paying Factories \\
\hline Phase I & 239 & 13 \\
Phase II & 100 & 7 \\
Phase III & 42 & 0 \\
Phase IV & 59 & 4 \\
Total & 440 & 24 \\
\hline
\end{tabular}

\section{Collection Route}

The study was conducted in three phases in Prai industrial area. GPS coordinate of collection points (locations of 24 companies) and Ampang jajar Waste Transfer Station identified through high-resolution GPS technology which can be classified as qualitative method. Secondly, the latitude and longitude coordinates for each station entered and mapped in GIS using "Add XY Data” method. Based on entered GPS coordinates, GIS is capable to identify the exact location of the collection points and waste transfer station. Table 3 represents the latitude and longitude of 24 companies in the Prai industrial area.

Table 3

Companies in Prai Industrial Zone Phase I, II and IV

\begin{tabular}{|c|c|c|c|c|}
\hline No & Phases & Company names & Latitude & Longitude \\
\hline 1 & I & Ann Joo & 5.381795 & 100.375432 \\
\hline 2 & & TNB Perai & 5.351284 & 100.410467 \\
\hline 3 & & POS MPSP & 5.361493 & 100.385988 \\
\hline 4 & & Irichi & 5.364293 & 100.391606 \\
\hline 5 & & ACM Perai & 5.358480 & 100.403987 \\
\hline 6 & & Parker & 5.354693 & 100.410798 \\
\hline 7 & & Food Court MPSP 5 & 5.353382 & 100.410995 \\
\hline 8 & & Food Court MPSP Per 6 & 5.352732 & 100.405341 \\
\hline 9 & & Food Court MPSP Per 8 & 5.354020 & 100.399807 \\
\hline 10 & & LBSB & 5.355230 & 100.410995 \\
\hline 11 & & Loytape Industry & 5.37598 & 100.387418 \\
\hline 12 & & Ann Joo & 5.381795 & 100.375432 \\
\hline 13 & & Mattel & 5.360842 & 100.398997 \\
\hline 14 & & Kastam (MPSP) & 5.356349 & 100.400581 \\
\hline 15 & II & Loytape Industry & 5.37598 & 100.387418 \\
\hline 16 & & Nation Gate & 5.379458 & 100.387001 \\
\hline
\end{tabular}


Table 3 (continue)

\begin{tabular}{|c|c|c|c|c|}
\hline No & Phases & Company names & Latitude & Longitude \\
\hline 17 & II & Food Court 3M & 5.369801 & 100.38913 \\
\hline 18 & & ILP Perai & 5.372186 & 100.389312 \\
\hline 19 & & Kastam & 5.367332 & 100.393474 \\
\hline 20 & & Bomba & 5.366582 & 100.3938781 \\
\hline 21 & IV & Ais Top & 5.353314 & 100.411877 \\
\hline 22 & & Food Court Maju 1 (Shell) & 5.351909 & 100.419253 \\
\hline 23 & & LRG Maju 1 (Bawal) & 5.347009 & 100.417776 \\
\hline 24 & & Kampung Dock & 5.345383 & 100.423161 \\
\hline
\end{tabular}

(Source: MBSP Depot \& Google Map)

\section{Geographical Information System (GIS)}

The Global Positioning System (GPS) technology was used to optimize the route by using collected data. GPS was used to collect data that later transferred and integrated in the GIS software. The Network Analysis extension in the GIS application was used to calculate the shortest distance. Location of the collection point, waste transfer station, and road network are also considered in the GIS software.

The standard measurement to determine the optimal route or path to specified destination is called metric. Optimal routes are determined by evaluating the metrics and these metrics differ depending on the nature of the routing algorithm. GIS is a widely used application in daily routine involving logistics and transportation industries. The GIS software transforms data from attribute table to topology maps.

\section{Dijkstra Algorithm}

Dijkstra algorithm is a one of the mathematical models used to find the shortest path. As noted by Ahuja et al. (1993), Dijkstra algorithm finds the shortest paths from point node $S$ (starting point) to all other nodes in a network with nonnegative arc lengths. Dijkstra algorithm provides a distance labelled $d(i)$ with each node $i$, which is an upper bound on the shortest path length to node $i$. At any intermediate step, the algorithm divides the nodes into two groups, which are permanent labelled and temporary labelled. The distance label to any permanent node is defined as the shortest distance from the source to that node. For any temporary node, the distance label is an upper bound on the shortest path distance to that node.

In Dijkstra algorithm, the operation of selecting the minimum distance is labelled as a node selection operation. The operation of checking whether the current labels for nodes $i$ and $j$ satisfy the condition $d(j)>d(i)+C_{i j}$ and, if so, then setting $d(j)=d(i)+$ $C_{i j}$ as a distance update operation. Each shortest path algorithm can determine the tree to 
calculate the shortest route distances. The existence of the shortest path tree relies on the following property.

Property 1.1. Ahuja et al., (1993). If the path $S=i_{2}-i_{2}-\ldots i_{h}=k$ is the shortest path from node $s$ to node $k$, then for every $q=2,3, \ldots, h-1$, the subpath $s=i_{1}-\mathrm{i}_{2}-\ldots$ $i_{q}$ is the shortest path from the source node to node $i_{q}$.

Let $d(-)$ denotes the shortest path. Property 1.1 mentioned that if $P$ is the shortest path from the source node to some node $k$, then $d_{(j)}=d_{(i)}+c_{i j}$ for every arc $(i, j)$ $\in P$., the converse of this result is also true; that is, if $d_{(j)}=d_{(i)}+c_{(i j)}$ for every arc in a directed path $P$ from the source to node $k$, then $P$ must be the shortest path. To establish this result, let $S=i_{2}-i_{2}-\ldots i_{h}=k$ be the node sequence in P. Then where $d\left(i_{1}\right)=0$. By assumption, $d(j)-d(i)=C_{i j}$ for every arc $(i, j) \in P$. using Equation 1.

$$
d(k)=c_{i_{h}-1 i_{h}}+C_{i_{h-2 i_{h-1}}}+\cdots \cdot C_{i_{1} i_{2}}=\sum_{i, j \in P} C_{i j}
$$

\section{Travelling Salesman Problem (TSP)}

As per the Dijkstra algorithm, TSP is also employed in ArcGIS to solve the shortest path. TSP employed any type of constraint that enforces the provision of the problem (Gutin \& Punnen, 2002). The below code is used:

$n=$ count of tour stops or count of nodes in the network

$i, j, k=$ indices of stops that can take integer values from 1 to $n$

$t=$ steps in the route between the stops

$x_{i j t}=1$ if the edge of the network from $i$ to $j$ is used in step $t$ of the route, 0 otherwise $d_{i j}=$ distance from stop $i$ to stop $j$

A simple version of the problem involves visiting subsequent stops from given locations (24 companies) and heading back to the starting point (cleaning depot). The perfect solution is one that minimizes a waste truck's overall travelled distance. The objective function $(\mathrm{Z})$ is the sum of all costs (distances) selected tour elements as shown in Equation 2:

Minimize

$$
Z=\sum_{i=1}^{n} \sum_{j=1}^{n} \sum_{t=1}^{n} d_{i j} x_{i j t}
$$

The tour is subject to the following constraints. Since the traveler cannot travel between more than one pair of stops at one time, for all values of $t$, exactly one arc must be traversed, hence (Equation 3): 


$$
\sum_{i=1}^{n} \sum_{t=1}^{n} x_{i j t}=1 \text { for all } i
$$

For each stop, $i$, there is just one other stop which is being reached from it, at some time, hence (Equation 4):

$$
\sum_{i=1}^{n} \sum_{t=1}^{n} x_{i j t}=1 \text { for all } t
$$

For all stops, there is some other stop from which it is being reached, at some time, hence (Equation 5):

$$
\sum_{i=1}^{n} \sum_{t=1}^{n} x_{i j t}=1 \text { for all } j
$$

When a stop is reached at time $t$, it must be left at time $t+1$, to exclude disconnected sub-tours that would otherwise meet all the above constraints. These sub-tour elimination constraints are formulated as (Equation 6):

$$
\sum_{i=1}^{n} x_{i j t}=\sum_{k=1}^{n} x_{j k t+1} \text { for all } j \text { and } t
$$

In addition to the above constraints, the decision variables must be integers taking only the value 0 or 1 (Equation 7):

$$
x_{i j t}=0,1 \text { for all } i, j, \text { and } t
$$

If $n$ is the number of stops to be visited, there are $(n-1)$ ! possible routes. As the number of stops increases computational time, it will be important to analyse all possible tours between stops to simply provide a problem that is difficult to solve. TSP is proven to be an NP-complete combination optimization problem (Bodin et al., 1983; Hoffman et al., 2013). Although specific large instances of the TSP have been solved with a combination of robust solution procedures and a great deal of computing power, the general difficulty in determining optimal solutions to even modest-sized instances of the TSP is the reason why heuristic solution procedures are employed in GIS applications. The serious consequence of employing those heuristics is the primary motivation for this article.

Like Dijkstra algorithm, TSP algorithm is also used to optimize the route. TSP is a classic algorithm to determine the minimum distance by selecting Closest Facility solution in GIS extension. Few methods and algorithms have been applied for optimizing routing system in SWM. 
TSP uses Hamiltonian cycle to optimize the route. Hamiltonian cycle is involving greedy method to resolve optimization problem. Then, the TSP method must find a route for all points visited by waste collection truck. The truck starts at cleaning depot (initial node) and visit all the collection points (intermediate node) exactly once and ends its journey at the same initial point (ending node).

\section{Carbon Emission}

UNFCCC (2017) sets $40 \%$ as the recommended limit for carbon emission which increases global warming, aims to strengthen the global response to climate change. Carbon emissions calculator used in this study is based on weight of waste and fuel consumption of waste truck attributes (Menikpura \& Sang-Arun, 2013).

Daily waste and fuel consumption data were obtained from MBSP Operations Manager. Table 4 shows the data of waste per month in the Prai industrial area for the existing route compared to alternative routes. Equation 8 is used to measure the carbon emissions.

Table 4

Weekly waste collection in Prai industrial area

\begin{tabular}{|c|c|c|c|}
\hline NO & Company & (kg) per Day & Collection \\
\hline 1 & Mattel & 1200 & 3 days /week \\
\hline 2 & Food Court 3M & 300 & Daily \\
\hline 3 & Kampung Dok & 300 & Daily \\
\hline 4 & Nation Gate & 800 & 2 days/week \\
\hline 5 & Ann Joo & 700 & 2 days/week \\
\hline 6 & Elna Sonic & 200 & 3 days/week \\
\hline 7 & Food Court MPSP 5 & 70 & Daily \\
\hline 8 & Food Court MPSP Per 6 & 70 & Daily \\
\hline 9 & Food Court MPSP Per 8 & 70 & Daily \\
\hline 10 & Kastam (MPSP) & 150 & 2 days/week \\
\hline 11 & Parker & 100 & 2 days/week \\
\hline 12 & LBSB & 100 & 2 days/week \\
\hline 13 & LRG Maju 1 (Bawal) & 100 & 2 days/week \\
\hline 14 & Food Court Maju 1 (Shell) & 90 & 2 days/week \\
\hline 15 & Loytape Industry & 50 & 3 days/week \\
\hline 16 & Kastam & 60 & 2 days/week \\
\hline 17 & ACM Perai & 100 & 1 day/week \\
\hline 18 & Bomba & 50 & 2 days/week \\
\hline 19 & Ais Top & 50 & 2 days/week \\
\hline 20 & ILP Perai & 60 & 1 day/week \\
\hline 21 & TNB Perai & 50 & 1 day/week \\
\hline 22 & POS MPSP & 50 & 1 day/week \\
\hline 23 & Irichi & 50 & 1 day/week \\
\hline \multirow[t]{2}{*}{24} & Dateline Resources & 10 & 2 days/week \\
\hline & Total & 4780 & \\
\hline
\end{tabular}

(Source: MBSP Depot) 
$\operatorname{Emission}_{T}(\mathrm{~kg})=\frac{\text { Fuel }(\text { unit })}{\text { Waste }(\mathrm{kg})} \times \operatorname{energy}(M J \backslash k g) \times E F\left(k g \backslash \mathrm{co}_{2}\right)$

Emission $_{\mathrm{T}}=$ Emission carbon from transportation $\left(\mathrm{kg} \mathrm{CO}_{2} /\right.$ tonnes of waste $)$

Fuel (unit) $=$ Total amount of fuel consumption per month, $($ diesel in liter $36.42 \mathrm{MJ} / \mathrm{L}$ and natural gas $37.92 \mathrm{MJ} / \mathrm{kg}$ )

$\mathrm{MJ}=$ amount of energy

$\mathrm{EF}_{\mathrm{CO} 2}=$ Emission Factors of $\mathrm{CO}_{2}$ of the fuel (e.g., diesel: $0.074 \mathrm{~kg} \mathrm{CO}_{2} / \mathrm{MJ}$, Natural gas: $0.056 \mathrm{~kg} \mathrm{CO} / \mathrm{MJ})$

\section{RESULTS AND DISCUSSION}

\section{Existing Route}

The GPS coordinates of companies located in Prai industrial area that getting MBSP waste collection services, processed through Network Analysis extension GIS tool to identify distance between one company to other companies. Name of the routes identified individually on the map. Figure 6 shows the input locations for GIS Network Analysis.

Figure 7 shows the attribute table for existing routes with a total length of $57.1 \mathrm{~km}$ based on outcome of GIS Network Analysis. MBSP truck driver using existing routes on daily basis to collect industrial waste and bring it over to Ampang Jajar waste transfer station. Movements between Prai industrial area and Ampang Jajar waste transfer station, passes through the North-South Highway.

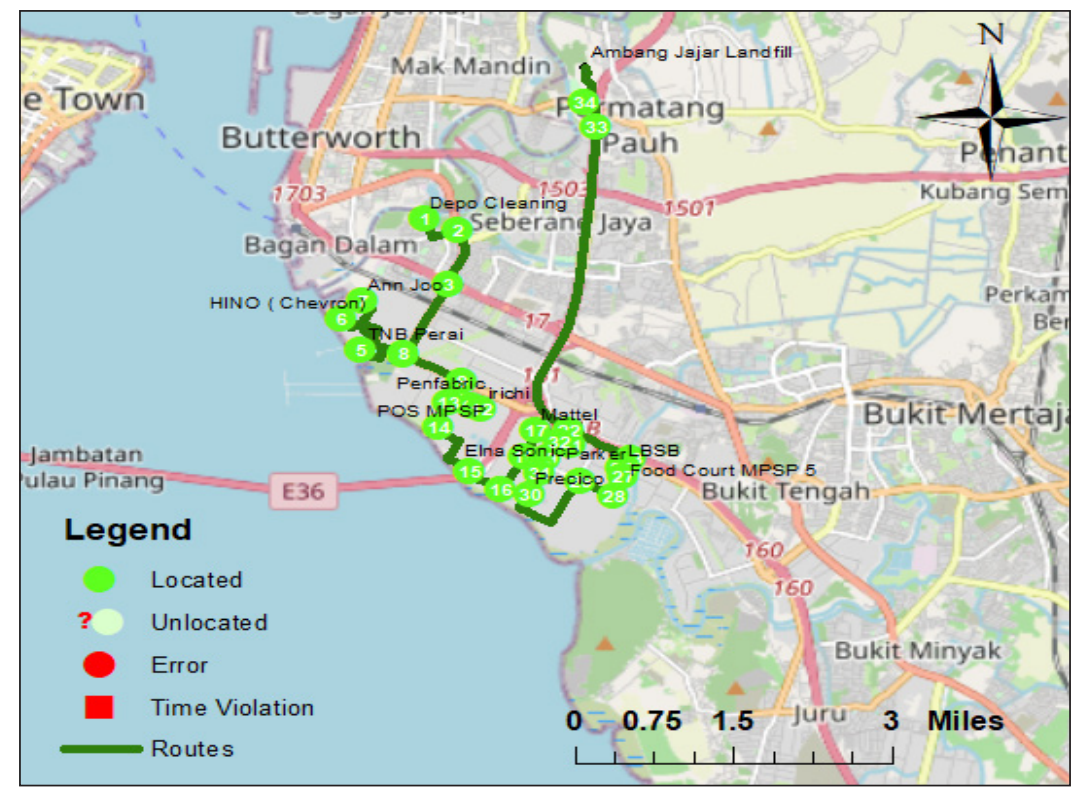

Figure 6. Existing route from Prai industrial area to Ampang Jajar waste transfer station 


\begin{tabular}{|c|c|c|c|c|c|c|c|}
\hline \multicolumn{8}{|c|}{ Routes } \\
\hline & ObjectlD & Shape & Name & FirstStoplD & LastStopID & StopCount & Total_Length \\
\hline , & 2 & Polyline II & Graphic Pick 1 - Graphic Pick 60 & 1 & 60 & 60 & 57050.087186 \\
\hline
\end{tabular}

Figure 7. Attribute table for existing route based on GIS Network Analyses

The GIS Network Analysis determined the weight and minimal distance between nodes (from one company to another), for each edge. The scanned image of the road viewed in geographic coordinates enables distances to be measured using GeoMedia's measuring tool to measure distances in GIS. Route distance was measured in kilometers, and the minimal distance between two companies was narrow.

\section{Alternative Route by Dijkstra Algorithm}

For the current study, the speed limit for all trucks was expected to be the same. The shortest route from each collection point to the waste transfer station was created in the Network Analysis extension. The route network consists of nodes (company locations), links connecting depot (initial node) and Ampang Jajar waste transfer station (end node).

Figure 8 shows the alternative route 1 by GIS Network Analysis, node by node. In this route, each company is visited only once, and the truck did not return to the depot. The alternative route $1(45.8 \mathrm{~km})$ is shorter compared to the existing route $(57.1 \mathrm{~km})$. The alternative route 1 uses a route that connects to North-South Highway before reaching waste transfer station as provided in spatial map in Figure 9.

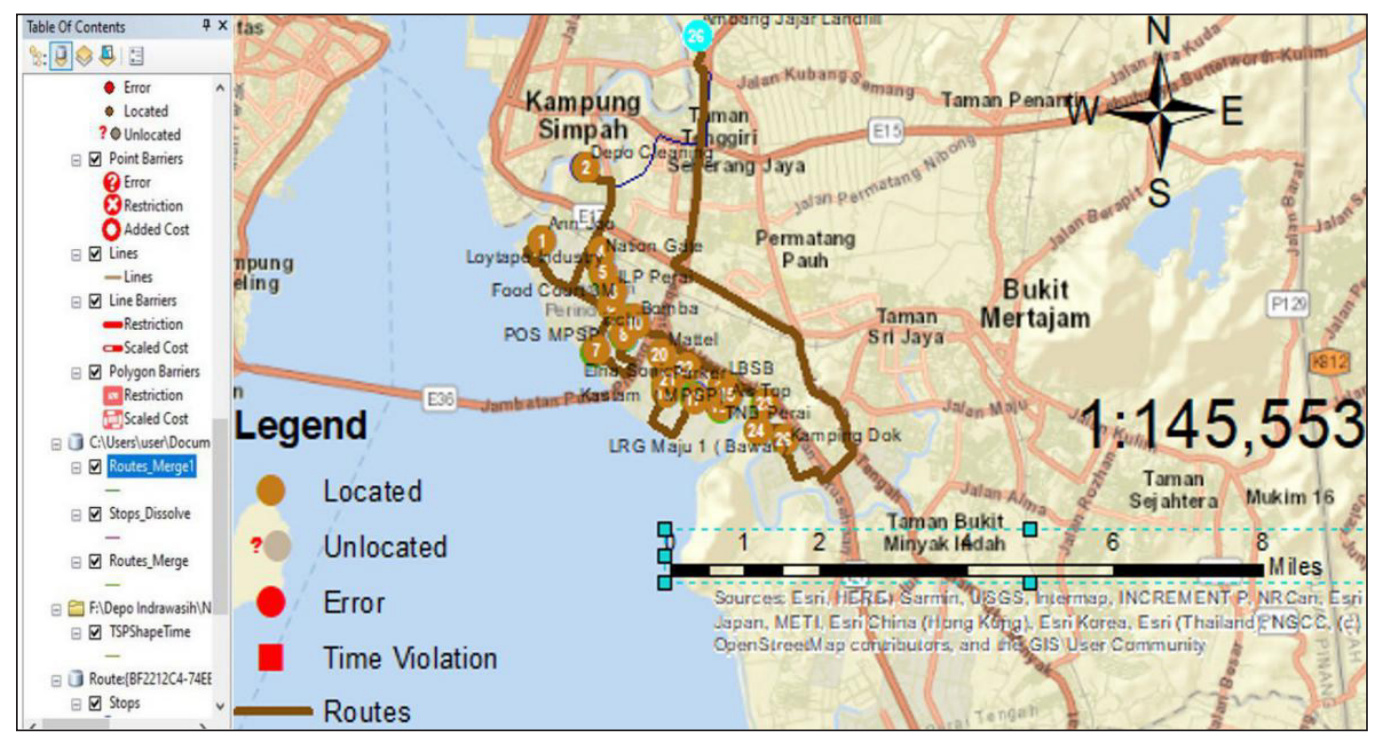

Figure 8. The alternative route 1 by GIS Network Analysis 


\begin{tabular}{|c|c|c|c|c|c|c|c|}
\hline & ObjectlD & Shape & Name & FirstStoplD & LastStopID & StopCount & Total_Length \\
\hline , & 7 & Polyline II & Location 1 - Location 26 & 1 & 26 & 26 & 45852.5988884 \\
\hline
\end{tabular}

Figure 9. The attribute table of alternative route 1 by GIS Network Analysis

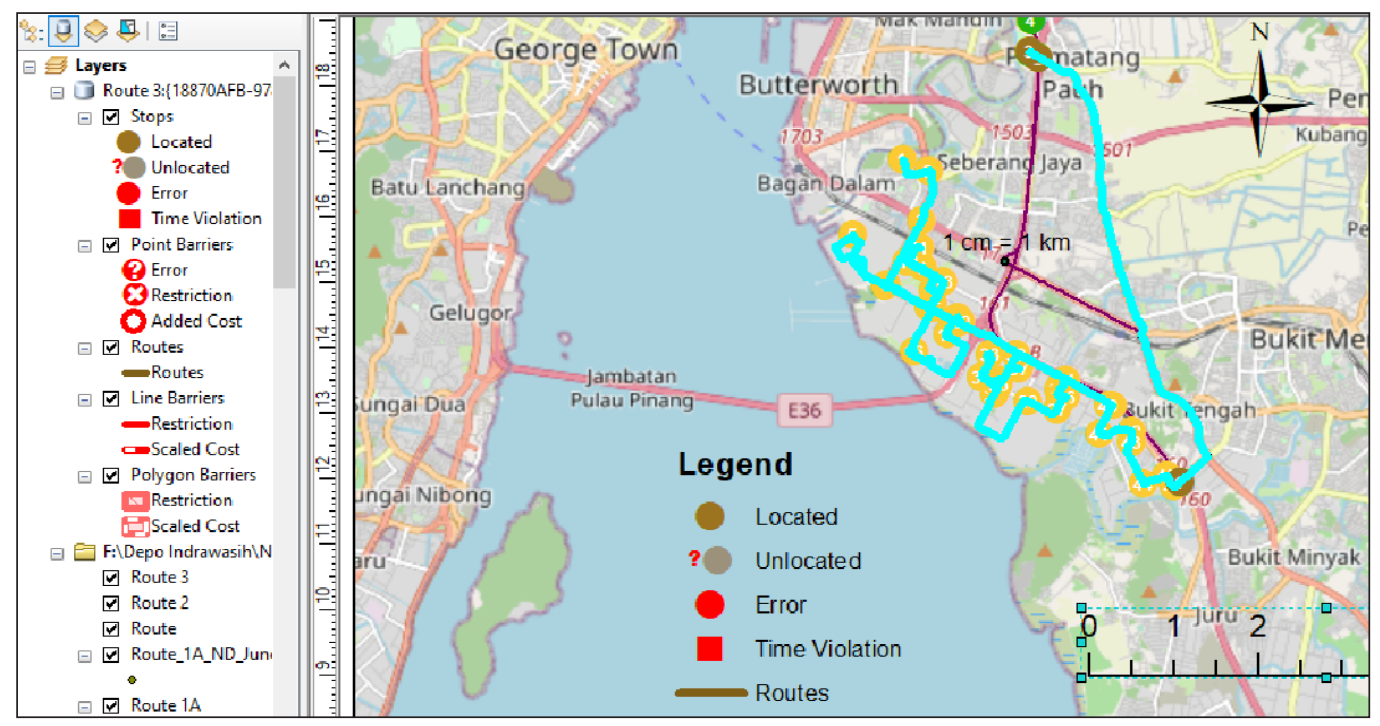

Figure 10. The alternative route 2 by GIS Network Analysis

\begin{tabular}{r|r|c|r|r|r|r}
\hline ObjectlD & Shape & Name & FirstStoplD & LastStoplD & StopCount & Total_Length \\
\hline 3 & Polyline II & Graphic Pick 1 - Graphic Pick 35 & 1 & 35 & 26 & $\mathbf{5 9 6 0 6 . 3 2 4 5}$ \\
\hline
\end{tabular}

Figure 11. The attribute table of alternative route 2 by GIS Network Analysis

Figure 9 is an attribute table, belonging to the spatial map shown in Figure 8, which shows the total length of each location. The total distance of traveling is also provided in this attribute table.

GIS Network Analysis also identified alternative route 2 which is $59.6 \mathrm{~km}$ in distance that connects to the Ampang Jajar waste transfer station through Bukit Tengah and Permatang Pauh. The alternative route 2 is longer than the existing route $(57.1 \mathrm{~km})$ by 2.5 $\mathrm{km}$. Figure 10 shows the alternative route 2 spatial map and Figure 11 shows the alternative route 2 attribute table.

\section{Traveling Salesman Problem (TSP) Algorithm}

In this study, the adopted TSP algorithm identifies the minimal closed path that begins at cleaning depot, goes to Ann Joo company, visits the rest of 23 companies exactly once 


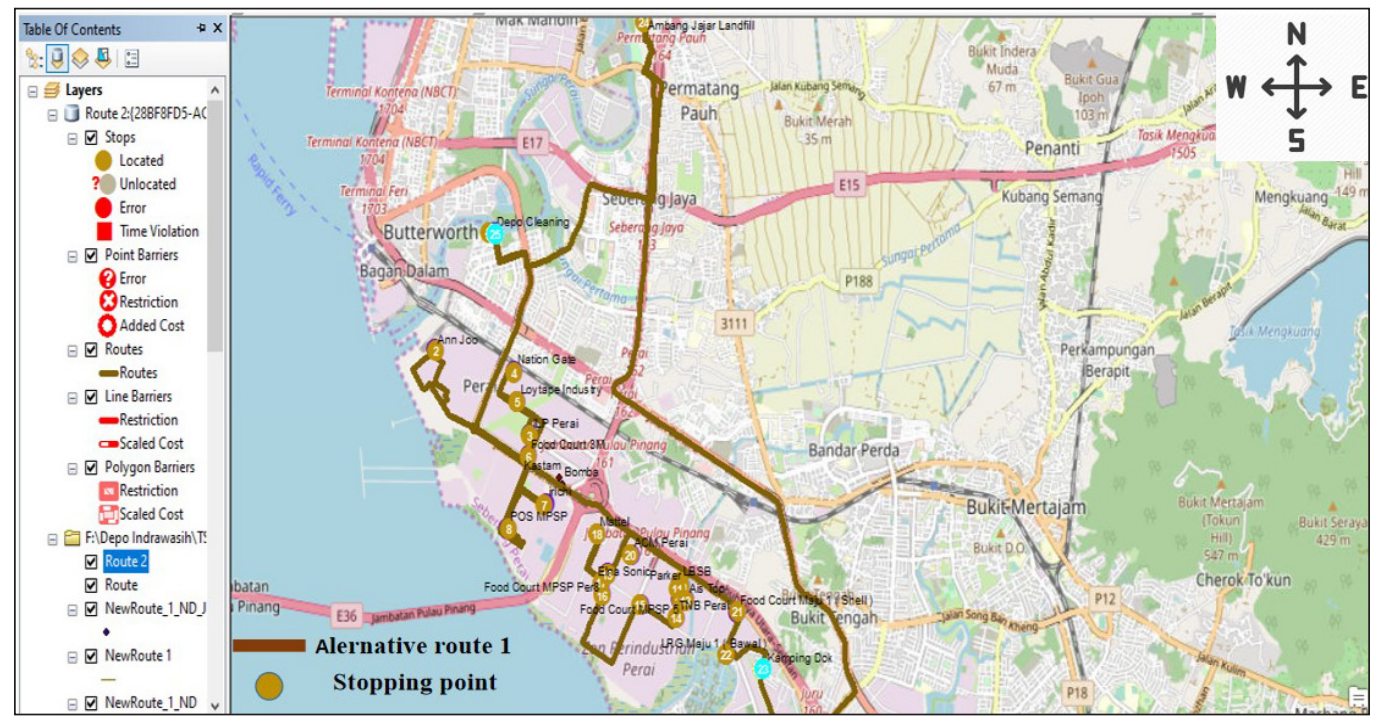

Figure 12. Propose Spatial Map of TSP table from GIS Network Analysis

Routes
\begin{tabular}{|r|r|c|c|r|r|r|r||}
\hline & ObjectlD & Shape & Name & FirstStoplD & LastStoplD & StopCount & Total_Length \\
\hline & 4 & Polyline II & Location 1 - Location 25 & 1 & 25 & 25 & 53250.801928 \\
\hline
\end{tabular}

Figure 13. The attribute table of location 1 to 25 creates from TSP Network Analysis

before returning to the same cleaning depot. This study found that the TSP method can minimize travelling distance and cost. Figure 12 is a TSP spatial map of the GIS Network Analysis that is connected to each node (company). The attribute table of location 1 to 25 created from TSP Network Analysis is as shown in Figure 13.

Bonomo et al. (2012) used the same method in the waste collection problem and found that Classic TSP method can optimize distance travelled using GIS system. The solution approach, employing graph theory, mathematical programming tools and data correction process were fully discussed in that study. The proposed method reduced the distance traveled by each collection vehicle between $10 \%$ to $40 \%$ compared to the existing routes.

\section{Comparison between Existing Routes and Proposed Routes}

GIS Network Analysis delivers route direction by counting route parameter to achieve objective. The study was intended to plan the cost-efficient waste collection route for transporting waste from Prai industrial area to Ampang Jajar Waste Transfer Station. Table 5 shows the shortest distance calculation by GIS software using Dijkstra and TSP algorithms compared to existing route. Distance between individual node (company) and 
total distance of identified routes summarized in the Table 5 in kilometer and percentage. The comparison is done using existing route as base.

The original collection route length is $57.7 \mathrm{~km}$, whereas the alternative route 1 and alternative route 2 proposed by GIS using Dijkstra algorithm are $45.8 \mathrm{~km}$ and $59.2 \mathrm{~km}$, respectively, while TSP proposed route is $53.3 \mathrm{~km}$. Figure 14 shows the comparison chart of existing and optimized routes in the studied area.

In Table 5, the nodes are represented by the company's name and distance between nodes is provided in kilometer $(\mathrm{km})$. Length of existing and alternative routes shown at the bottom of Table 5. The comparison represented in kilometer variance and percentage.

Table 5

Comparison of Shortest Path by Using GIS

\begin{tabular}{|c|c|c|c|c|c|}
\hline \multirow[b]{2}{*}{ From Node } & \multirow[b]{2}{*}{ To Node } & \multirow{2}{*}{$\frac{\text { Existing }}{(\mathrm{km})}$} & \multicolumn{2}{|c|}{ (DJ) } & \multirow{2}{*}{$\frac{\mathrm{TSP}}{(\mathrm{km})}$} \\
\hline & & & Alt $1(\mathrm{~km})$ & Alt $2(\mathrm{~km})$ & \\
\hline Depot & Ann Joo & 5.1 & 5.1 & 5.1 & 5.1 \\
\hline Ann Joo & ILP Perai & 8.1 & 8.2 & 8.1 & 8.1 \\
\hline ILP Perai & Nation Gate & 9.6 & 9.6 & 9.6 & 9.6 \\
\hline Nation Gate & LoyTape Industry & 10.3 & 10.3 & 10.3 & 10.3 \\
\hline Loytape Industry & Food Court 3M & 11.3 & 11.4 & 11.3 & 11.3 \\
\hline Food Court 3M & Irichi & 12.2 & 13.7 & 12.2 & 12.2 \\
\hline Irichi & Pos MBSP & 13.5 & 17.2 & 13.5 & 13.5 \\
\hline Pos MBSP & Kastam & 20.3 & 17.3 & 20.3 & 20.3 \\
\hline Kastam & Bomba & 20.4 & 19.8 & 20.4 & 20.4 \\
\hline Bomba & LBSB & 20.6 & 19.9 & 20.6 & 20.6 \\
\hline LBSB & Dateline Resources & 20.8 & 20 & 20.8 & 20.8 \\
\hline Dateline Resources & Parker & 20.9 & 20.2 & 20.9 & 20.9 \\
\hline Parker & FC5 & 21.2 & 20.3 & 21.2 & 21.2 \\
\hline FC5 & Ais Top & 21.9 & 20.6 & 21.7 & 21.9 \\
\hline Ais Top & TNB Perai & 24.1 & 21.3 & 22.0 & 24.1 \\
\hline TNB Perai & FC6 & 24.4 & 23.5 & 24.6 & 24.4 \\
\hline FC6 & FC8 & 25.4 & 23.8 & 24.9 & 25.4 \\
\hline FC8 & Elna Sonic & 26.4 & 24.8 & 25.9 & 26.4 \\
\hline Elna Sonic & Mattel & 27.3 & 25.8 & 26.9 & 27.3 \\
\hline Mattel & ACM Perai & 30 & 26.7 & 27.8 & 30 \\
\hline ACM Perai & FC 1(Shell) & 30.7 & 29.3 & 30.5 & 30.7 \\
\hline FC 1(Shell) & Bawal Shop & 31.8 & 30.1 & 30.8 & 31.8 \\
\hline Bawal Shop & Kampung Dock & 45.1 & 31.2 & 32.2 & 32.9 \\
\hline Kampung Doc & Landfill & $\underline{57.07}$ & $\underline{45.8}$ & $\underline{59.2}$ & 46.6 \\
\hline Landfill & Depot & 64.10 & & & $\underline{\underline{53.3}}$ \\
\hline \multicolumn{2}{|c|}{ Compare with the existing route (KM) } & & -11.9 & 2.13 & -3.77 \\
\hline \multicolumn{2}{|c|}{$\%$} & & $-19.74 \%$ & $3.73 \%$ & $-6.61 \%$ \\
\hline
\end{tabular}


The negative value indicating shorter travelling distance (optimal results) while positive value reveals increase in travelling distance. Based on results show in Table 5, alternative route 2 is longer by 2.13 kilometer compared to existing route.

In Table 5, the total distance between nodes was calculated. The distance between starting node Depot to node Ann Joo is about $5.1 \mathrm{~km}$ and accumulated distance from Ann Joo to ILP Perai is $8.1 \mathrm{~km}$. The variance of 3 kilometer is the net distance between Ann Joo to ILP Perai. Similarly, accumulated distance between node ILP Perai to node Nation Gate is 9.6 kilometer in existing route. The variance of 1.5 kilometer is the net distance between these 2 places. This accumulation of distance happens between nodes until the final node (destination). The sum represents total length of entire route.

Comparing the existing route with alternative route 1 results in a $19.74 \%$ reduction of distance. While the alternative route 2 involves $3.73 \%$ more distance compared with existing route. Although alternative route 2 is longer than existing route, the MBSP management still can use this route when the existing route is under construction or there is traffic congestion on the normal route.

The TSP method can minimize the distance approximately by $6.61 \%$ compared to existing route. This method is more effective in identifying the shortest distance compared to Dijkstra algorithm. The Dijkstra algorithm uses directed path which does not include returning to the initial node while the TSP method returns to the initial node (depot). As per information from MBSP Operations Manager, all the collection trucks will be parked at the cleaning depot at the end of every collection trip. So, the TSP method can identify the shortest route more effectively when the day trucks return to the depot by end of daily waste collection operations.



Figure 14. Comparison chart of existing and alternative routes from Prai industrial area to Ampang Jajar Waste Transfer Station. 
Kalle et al. (2016) proved that use of GIS can reduce collection time, distance travelled and fuel consumption. Also, they found that GIS also reduces working hours, vehicles wear and maintenance cost. In addition, Zam et al. (2007) also proved that GIS minimizes operational costs by optimizing routes in residential areas.

\section{Cost of Operation}

After determining minimum distance, this study also compared the cost of diesel utilized by existing route and alternative routes. The diesel cost is important in determining travelling cost. The diesel price during the study was approximately RM 3 per liter. MBSP Operations Manager mentioned that 700 liters of diesel is consumed by the truck per month.

Table 6 clearly sets out the calculation of diesel cost of waste collection truck for existing route and alternative routes. Figure 15 demonstrates, monthly diesel usage cost reduced from RM 2100.00 to RM 1685.40 (-19.75\%) for alternative route 1. Use of

Table 6

Comparison of fuel cost for existing and alternative routes

\begin{tabular}{lcccc}
\hline & Existing Route & DJ-Alt 2 & DJ-Alt 2 & TSP \\
\hline Total waste per month (24 Companies), kg & 4780 & 4780 & 4780 & 4780 \\
Diesel cost, RM/ $l$ & 3 & 3 & 3 & 3 \\
Diesel consumption/ month, $l$ & 700 & & & \\
Diesel consumption/ day, $l$ & 23.33 & & & \\
Total travelled distance/ month, km & 1712.1 & 1374.0 & 1776.0 & 1599.0 \\
Diesel consumption/ km, $l$ & 0.4089 & 0.4089 & 0.4089 & 0.4089 \\
Diesel consumption/ month, $l$ & 700.0 & 561.8 & 726.2 & 653.8 \\
Diesel cost/ month, RM & 2100.00 & 1685.40 & 2178.60 & 1961.40 \\
Cost variance, \% & - & $-19.75 \%$ & $+3.71 \%$ & $-6.62 \%$ \\
\hline
\end{tabular}

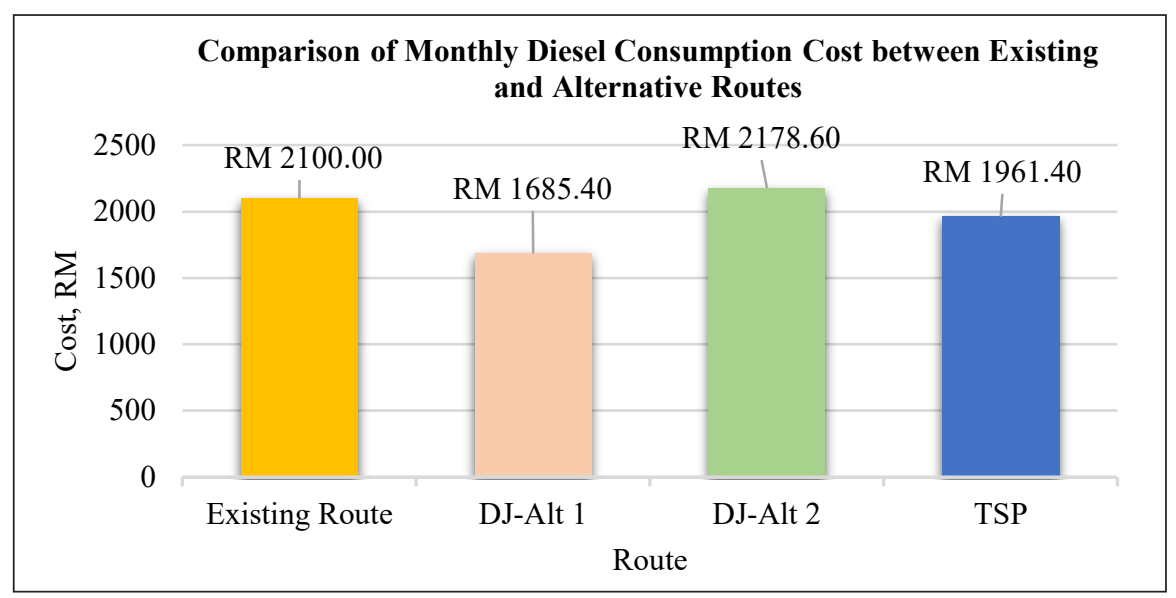

Figure 15. Comparison of monthly diesel consumption cost between existing and alternative routes. 
alternative route 2 will increase the cost by RM $178.60(+3.71 \%)$ monthly due to increase in use of diesel consumption. The TSP method resulted in lower diesel cost as well, reduced by RM 138.60 (-6.62\%). The diesel cost calculation for TSP method is higher due to return of waste collection truck to cleaning depot or initial starting point. State of Penang spends approximately RM 1 billion for waste management cost alone. This amount can be reduced by optimizing travel routes of waste collecting trucks which leads to overall fuel cost savings. Many researchers used GIS techniques to minimize overall cost of management that involves road travel. Other research (Kinobe et al., 2015; Ahmad, 2016; Kalle et al., 2016; Beijoco et al., 2011) also successfully reduced the cost of SWM transportation by implementing Dijkstra and TSP algorithm methods.

By finding effective routes, not only the cost of diesel is reduced but the savings can be extended to labor cost, traveling cost, daily output or coverage, and truck maintenance cost. The result of this study suggests that MBSP can invest additional fund for truck maintenance to increase efficiency of waste collection process.

\section{Carbon Emission}

After determining the diesel cost, this research compares the carbon emission levels for the existing route and alternative routes from Prai industrial area to Ampang Jajar waste transfer station using Equation 8. The total monthly waste of 24 companies and amount of diesel used by waste truck were recorded. From Equation 8, the energy released per liter of diesel is approximately 36.42 and emission factor per liter is 0.74 . Table 7 represents the standard of energy content and emission factor in each liter of fuel.

After determining the travelling cost, this research compares the carbon emission levels for the existing route and alternative routes from Seberang Perai industrial area to Ampang Jajar waste transfer station. The Equation 8 was built to calculate carbon emission from transportation in Seberang Perai industrial area to waste transfer station Ampang Jajar. Therefore, the total waste of 24 companies every month and the amount of diesel used by waste truck every month was recorded. In Equation 8, the energy that released per liter

Table 7

Calculation of Carbon Emission in for existing and alternative routes

\begin{tabular}{|c|c|c|c|c|}
\hline & Existing route & Alt 1 & Alt 2 & TSP \\
\hline Energy Content Per liter & 36.42 & 36.42 & 36.42 & 36.42 \\
\hline Emission Factor Per liter & 0.074 & 0.074 & 0.074 & 0.074 \\
\hline Monthly waste disposal, kg & 143,400 & 143,400 & 143,400 & 143,400 \\
\hline Monthly fuel consumption, liter & 700.0 & 561.8 & 726.2 & 653.8 \\
\hline $\mathrm{CO}_{2}$ Emission $_{\mathrm{T}}$ per month (kg) & 0.013 & 0.011 & 0.014 & 0.012 \\
\hline $\mathrm{CO}_{2}$ Emission $_{\mathrm{T}}$ per year $(\mathrm{kg})$ & 0.158 & 0.127 & 0.164 & 0.147 \\
\hline Changes in $\mathrm{CO}_{2}$ Emission $_{\mathrm{T}}, \%$ & - & -19.6 & $+3.8 \%$ & -7.0 \\
\hline
\end{tabular}


of diesel is approximately 36.42 and emission factor per litter approximately 0.74 . Table 7 represent the standard of energy content and emission factor that is in each liter of fuel.

Carbon emission for the existing route is $0.013 \mathrm{~kg}$ per month, or $0.158 \mathrm{~kg}$ per year. Alternative route 1 reported carbon emission level at $0.011 \mathrm{~kg}$ per month, or $0.127 \mathrm{~kg}$ per year. Alternative route 2 reported slightly higher level of carbon emission; is $0.014 \mathrm{~kg}$ per month, or $0.164 \mathrm{~kg}$ per year. The carbon emission for TSP method is $0.012 \mathrm{~kg}$ per month, or $0.147 \mathrm{~kg}$ per year. Alternative route 1 is having lower emission by $19.6 \%$ compared to existing route. Similarly, TSP method is also reported lower emission rate by $7.0 \%$. Alternative route 2 reported higher carbon emission level by $3.8 \%$ due to longer travelling distance. This reveals route optimization can reduce carbon emission and contributes to greener, cleaner, and healthier state. This finding is aligned with Ghadimzadehi et al. (2015) which found that decreased fuel consumption reduces $\mathrm{CO}_{2}$ emission from vehicles.

\section{CONCLUSION}

The study found that Dijkstra and TSP algorithms are useful to optimize the distance and transportation cost for solid waste management in Prai industrial area via the use of GIS approach by MBSP. The optimum route saves the travelling distance and fuel cost compared to existing route evaluated through Arc Map Network Analysis. The analysis revealed alternative route 1 as the shortest route. This study helps MBSP to control the cost of waste management in terms of travelled distance, fuel, time, and labour. These shortest paths also help MBSP to understand alternative routes in the case of construction or route crowding. The positive outcome of this study is important to achieve the Penang 2030 vision.

\section{ACKNOWLEDGMENTS}

We would like to thank the MBSP Waste Management Team that assisted by providing necessary information and School of Mathematical Sciences, University Science Malaysia for the funding.

\section{REFERENCES}

Ahmad, F. I. (2016). Sustainable solutions for domestic solid waste management in Qatar (MSc Thesis). Qatar University, Doha, Qatar.

Ahuja, R. K., Magnanti, T. L., \& Orlin, J. B. (1993). Network flows: Theory, algorithms, and applications. Pearson Prentice Hall.

Anghinolfi, D., Paolucci, M., Robba, M., \& Taramasso, A. C. (2013). A dynamic optimization model for solid waste recycling. Waste Management, 33(2), 287-296. https://doi.org/10.1016/j.wasman.2012.10.006

Beijoco, F., Semiao, V., \& Zsigraiova, Z. (2011). Optimization of a municipal solid waste collection and transportation system. Journal of Waste Management, 4(33) 793-806. 
Bhambulkar, A. V. (2011). Municipal solid waste collection routes optimized with arc GIS network analyst. International Journal of Advanced Engineering Sciences and Technologies, 11(1), 202-207.

Bodin, L. (1983). Solving large vehicle routing and scheduling problems in small core. In Proceedings of the 1983 annual conference on Computers: Extending the human resource (pp. 27-37). Association for Computing Machinery. https://doi.org/10.1145/800173.809693

Bonomo, F., Durán, G., Larumbe, F., \& Marenco, J. (2012). A method for optimizing waste collection using mathematical programming: A Buenos Aires case study. Waste Management \& Research, 30(3), 311-324. https://doi.org/10.1177/0734242X11402870

Bovwe, O., Nwaogazie, I. L., \& Agunwamba, J. C. (2016). Development of ant colony optimization software as a solid waste management system. Current Journal of Applied Science and Technology, 15(5), 1-19. https://doi.org/10.9734/BJAST/2016/25080

Chipumuro, M., Mawonike, R., \& Makoni, T. (2014). Optimizing routing of residential solid waste collection: Case study of Chikova residential area in Zimbabwe. International Research Journal of Mathematics, Engineering \& IT, 1(3), 23-40.

Ghadimzadeh, A., Makmom, A. A., Hosea, M. K., Asgari, N., Shamsipour, R., Askari, A., \& Narany, T. S. (2015). Review on CO2 Emission from Transportation Sector in Malaysia. IOSR Journal of Environmental Science, Toxicology and Food Technology, 9(5), 61-70. https://doi.org/10.9790/2402-09516170

Ghose, M., Dikshit, A., \& Sharma, S. (2006). A GIS based transportation model for solid waste disposal - A case study on Asansol municipality. Journal of Waste Management, 26(11), 1287-1293. https://doi. org/10.1016/j.wasman.2005.09.022

Gutin, G., \& Punnen, A. P. (2002). Traveling salesman problem and its variations. Kluwer Academic Publishers.

Hoffman, K. L., Padberg, M., \& Rinaldi, G. (2013). Traveling salesman problem. Encyclopedia of operations research and management science, 1, 1573-1578. https://doi.org/10.1007/1-4020-0611-X_1068

Kalle, A., Mohamed, M. S., \& Moncef, Z., (2016). Using GIS-based tools for the optimization of solid waste collection and transport: Case study of Sfax City, Tunisia. Journal of Engineering, 2016, Article 4596849. https://doi.org/10.1155/2016/4596849

Kinobe, J., Bosona, T., Gebresenbet, G., \& Niwag, C. (2015). Optimization of waste collection and disposal in Kampala city. Journal of Habitat International, 49, 126-137. http://dx.doi.org/10.1016/j. habitatint.2015.05.025

Kumpulan Utusan. (2017). Utusan Melayu (M) Berhad. Retrieved January 24, 2018, from http://www.utusan. com.my

Menikpura, N., \& Sang-Arun, J. (2013). User manual estimation tool for greenhouse gas (GHG) emissions from municipal solid waste (MSW) management in a life cycle perspective. Institute for Global Environmental Strategies.

National Solid Waste Management Department. (2013). Survey on solid waste composition, characteristics \& existing practice of solid waste recycling in Malaysia. Retrieved December 13, 2018, from https:// jpspn.kpkt.gov.my 
Nguyen-Trong, K., Nguyen-Thi-Ngoc, A., Nguyen-Ngoc, D., \& Dinh-Thi-Hai, V., (2017). Optimization of municipal solid waste transportation by integrating GIS analysis, equation-based, and agent-based model. Journal of Waste Management, 59, 14-22. https://doi.org/10.1016/j.wasman.2016.10.048

Penang State Government. (2016). Official portal Penang state government. Retrieved August 23, 2018, from https://www.penang.gov.my/en/awams

Omran, A., El-Amrouni, A. O., Suliman, L. K., Pakir, A. H., Ramli, M., \& Aziz, H. A. (2009). Solid waste management practices in Penang State: A review of current practices and the way forward. Environmental Engineering \& Management Journal (EEMJ), 8(1), 97-106. https://doi.org/10.30638/eemj.2009.014

Patel, M. H., Padhya, P. H., \& Zaveri, P. P. (2016). GIS based route optimization for solid waste management: A case study of Surat City. International Journal for Scientific Research \& Development, 4(04), 32-34.

Shamshiry, E., Nadi, B., \& Mahmud, A. R. (2011). Optimization of municipal waste management. International Proceedings of Chemical, Biological and Environmental Engineering, 1(1), 119-121.

Singh, G., Singh, B., Rathi, S., \& Haris, S. (2014). Solid waste management using shortest path algorithm. International Journal of Engineering Science Invention Research \& Development, 1(2), 60-64.

Stewart, L. A. (2005, July 25-29). The application of route network analysis to commercial forestry transportation. In Proceedings of 2005 ESRI International User Conference. San Diego, USA.

Tavares, G., Zsigraiova, Z., Semiao, V., \& Carvalho, M. D. G. (2008). A case study of fuel savings through optimization of MSW transportation routes. Management of Environmental Quality: An International Journal, 19(4), 444-454. https://doi.org/10.1108/14777830810878632

Williams, R. (2012). Globalization and waste management. International Solid Waste Management, Singapore.

Zam, D., Jamtsho, S., Dema, T., \& Wangmo, J. C. C., (2007). Optimization of solid waste collection and transportation route in Phuentsholing city using GIS. Journal of Academia, 1-8. 